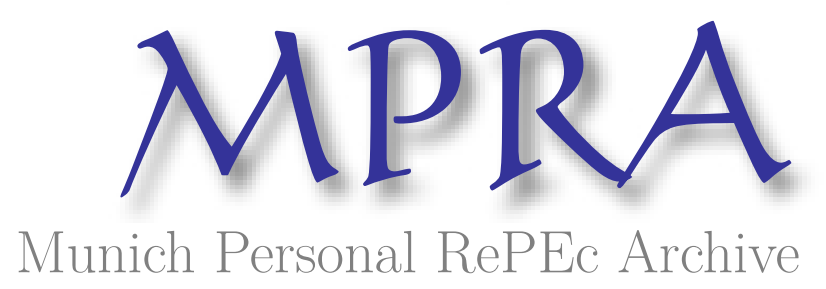

\title{
Human Development Disparities and Convergence across Districts of Indonesia: A Spatial Econometric Approach
}

Miranti, Ragdad Cani and Mendez-Guerra, Carlos

Nagoya University, Nagoya University

April 2020

Online at https://mpra.ub.uni-muenchen.de/102453/

MPRA Paper No. 102453, posted 16 Aug 2020 11:56 UTC 


\title{
Human Development Dynamics across Districts of Indonesia: A Study of Regional Convergence and Spatial Approach
}

\author{
Ragdad Cani Miranti ${ }^{1}$ and Carlos Mendez ${ }^{2}$ \\ ${ }^{1}$ Graduate School of International Development, Nagoya University, Aichi \\ 464-8601, Japan; miranti.ragdad.cani@g.mbox.nagoya-u.ac.jp \\ ${ }^{2}$ Graduate School of International Development, Nagoya University, Aichi \\ 464-8601, Japan; carlos@gsid.nagoya-u.ac.jp
}

\begin{abstract}
:
Indonesia is an archipelago country which comprises of two main parts, western and eastern regions and spread into over 500 districts. Each district has their own characteristics, especially in development aspect. Some districts have been growing faster on economic and social development, yet others still fall behind. Using Human Development Index and its components on education, health and economic variables over 2010- 2018 period, this study aims to examine convergence on the regional human growth process and investigate the speed of convergence across districts. The result reveals convergence occurred on human development process and its determinants across districts during 2010-2018. Education variables are assumed as the main contributor for boosting the speed of convergence of human development. Spatial dependences are detected among districts, followed by the spatial clusters and spatial outliers through global and local spatial autocorrelation. Applying two spatial autoregressive models, spatial autoregressive lag model (SAR) and spatial autoregressive error model (SEM), confirmed that there is significant spatial spillovers. The speed of convergence for all variables are much declining after the inclusion of spatial lag and error model. As the policy implication, since regional inequality in term of human development is still a major issue, it will be a call for better coordination and cooperation within and between regions.
\end{abstract}

Keyword : Indonesia, human development, convergence, spatial approach, district 


\section{Introduction}

The creation of human development approach to expand peoples' freedoms covers for both the main purpose and the underlying principal for sustainable development. If inequalities of human development are persistent and keep growing, the goals of the 2030 Agenda for Sustainable Development will not be fulfilled still. Human Development Index were formulated by UNDP in 1990 as the composite index for evaluating long-run achievement on three fundamental key aspects of human capital growth: long life, education and knowledge access and good living standard.

Since some last decades, the development of Indonesia has already emerging and going towards the upper-middle-income country, yet the inequality still remains wide until recently. Indonesia is an archipelago country that spread over more than 500 districts, categorized into two main parts, western and eastern part of regions. Evidence in the past said that the eastern part of regions were falling behind and less developed compared to another part. Nevertheless, convergence studies claim that the less advantages regions would catch up their falling behind status and grow faster than the more developed regions. This condition was confirmed by the convergence studies that stating the diminishing marginal returns to capital in the more developed regions, as the level of capital per labor is relatively high in these regions. This leaded in turn to catch up convergence.

Indonesia offers an attractive case for exploring human capital growth at district level for some reasons. First, its human capital growth measured by Human Development Index across districts over time are growing better within last decade with the diversity of characteristics and development level on each district. Second, from the number of studies about human development in Indonesia, only a few that include convergence analysis and spatial approach in the growth process for district level. In addition, a few studies concern on the human development and its indicators using the very latest data, 2010 onwards. Third, evidence by Vidyattama (2013) using HDI data before and after decentralization period (1999-2008) found that regional convergence was occurring both in province and district level and the proof of how neighborhood effect or so-called 'spill-over' effect was also significantly affecting the regional convergences. However, there was only less 
effect on the speed of convergence. The broad insight about Indonesia's growth story across districts is the existence of broad development disparity. It has been more than a decade after Indonesia's decentralization era was started, it ascertained the changing pattern from development performance, unexceptionally for regional growth which can be approached through both GRDP per capita and Human Development Index as well. These two proxies might be still debatable for the measurement, nevertheless HDI has been broadly used, especially in studies of developing nations (Anand and Sen 2000).

Given this research landscape, we draw some research questions as the extension of the previous studies and another contributions to address: (i) Does convergence occur in term of human development growth across districts? (ii) Is there any spatial dependence in the human capital growth process of Indonesia districts? (iii) What is the major driver among three its indicators for boosting convergence process of Human Development Index on district level? (iv) How far do spatial spill-over effect contribute a role in the process of convergence?

\section{Literature Review}

Many studies explored about the regional development and its convergence. Doso and Pentecost (2011) using panel from 1991-2008 has proved a positive impact on regional growth and convergence since the skills needed to adopt the new technologies are derived by higher levels of education. Specific to the human capital studies, Ramos, Suriñach and Artis (2009) using data from 1980-2005 declared a positive role of human capital in secondary studies on regional growth yet the presence of negative geographical spillovers correlated with tertiary studies. These studies also claimed that characteristics across regions would share both direct and spatial spill-over effects for the income of its regions and the neighborhoods.

Long years before, Garcia-Garcia and Soelistianingsih (1998) has already shown to produce the first estimation of the income speed of convergence on Indonesia's provincial level within 1975-1983 that indicated significant convergence of per capita GRDP and predicted its speed to be approximately of 2 percent. These findings are in line with the theory of Sala-I-Martin (1996) stating convergence is more obtainable for a sub-national level, impacting to larger 
influence among smaller levels of region as economic units. It also implies that the neighborhood effect seems to exist more among smaller levels of region. Other reasonable finding that appears on regional studies for the neighborhood effect is that the administrative borders which are used by regions do not essentially figure the economic activities' borders (Le Sage 1999; Rey 2001). Consequently, some economic activities across or within borders, for instance commuting and trade, connect the economic progresses of the regions included, then a change of economic condition in a region economy might influence greatly to that of another.

In particular, for some case studies of other countries, Abreu, de Groot and Florax (2004) have verified on their analysis of many studies that applied on spatial regression. Findings of Cravo, Becker, and Gourlay (2015), Resende et al. (2016) and Lima and Neto (2016) focus on economic growth on sub-national level in Brazil affirmed the existence of neighborhood effects in the process of convergence. In addition, in European Union (EU) studies Mohl and Hagen (2010), Cuaresma, Doppelhofer, and Feldkircher (2014) also indicated proof for spatial spill-overs positively, which means region takes advantage for growth or development process from its neighbors. Specific to Indonesia's case study, Resosudarmo and Vidyattama (2006) found evidence that regional income per capita convergence existed on province level of Indonesia using data from the 1993 to 2002 period to examine the determinants of income discrepancy on regional level. Anwar (2018) confirmed the existence of convergence for absolute and conditional way by observing human capital growth between two periods, 2004-2010 and 2010-2016. Kharisma, Bayu (2013) also conducted the convergence analysis of income on provincial level in Indonesia from 1984 to 2008 and declared there was a strong existence of absolute and conditional convergence on his case.

\section{Methodology and Data}

\subsection{The Framework of Classical Convergence}

The theories of classical convergence empirically has been implemented on a number of comprehensive collection of studies. Barro and Sala-i-Martin (1991, 1992a, 1992b) findings has been significantly affecting. Their findings especially was begun by supposing the average growth rate of output per worker. In this 
paper, the data of Human Development Index is utilized over an interval of time period $t$, beginning at 0 . The formula is as follow:

$$
\frac{1}{t} \log \left(\frac{y_{t}}{y_{0}}\right)=\varphi+\frac{\left(1-e^{-\beta t}\right)}{t}\left(\log \tilde{y}^{*}+\log A_{0}\right)-\frac{\left(1-e^{-\beta t}\right)}{t} \log y_{0}
$$

where $\beta$ is the speed magnitude or often called with speed of convergence in which represents the economic condition converges against its steady state, for $y_{0}$ is the starting/initial output, $\frac{1}{t} \log \left(\frac{y_{t}}{y_{0}}\right)$ is the average growth rate for time 0 and $\mathrm{t}$, while $\varphi$ is the exogenous growth of technology. $A_{0}$ is the starting level of technology while $\tilde{y}^{*}$ is the steady-state output value for each effective worker. The new equation will be generated when a collection of regions contribute to a general technological and institutional atmosphere, as follows:

$$
\frac{1}{t} \log \left(\frac{y_{t}}{y_{0}}\right)=-\frac{\left(1-e^{-\beta t}\right)}{t} \log y_{0}
$$

Thus, first parameter, the speed of $\beta$-convergence can be estimated through the regression model as follows:

$$
\frac{1}{t} \log \left(\frac{y_{t}}{y_{0}}\right)=\gamma-\frac{\left(1-e^{-\beta t}\right)}{t} \log y_{0}+u_{t}
$$

Referring to Equation 3 above, $\gamma$ is constant and $u_{t}$ is a random nuisance which represents unforeseen changes in preferences, technologies or institutions. For the second parameter, half-life, can be calculated as

$$
\text { half }- \text { life }=\frac{\log 2}{\beta}
$$

Meanwhile, sigma convergence is likely the more common idea of convergence which complements to the analysis of beta convergence. It explains the shrinking of the variation of cross-sectional variables or indicators (for example human development or GDP growth) over time. Beta convergence may determine the sigma convergence, however Quah (1992) and Sala-i-Martin (1996) on their reviews stated that beta convergence will not always be an adequate condition for achieving sigma convergence. 


\subsection{Spatial Autocorrelation Framework}

\subsubsection{Global Spatial Autocorrelation}

This framework shows the whole grouping of a variable in location and is represented by Moran's I statistics. Anselin (1995) and Anselin et al. (2007) declared that Moran's I statistics describes the strength or degree of linear correlation from the value of variable in a region with the spatially lagged values. Spatially lagged values are weighted spatially average of values at neighborhood regions. At a point of time $t$, The Moran's I statistic is given by:

$$
I_{t}=\frac{N}{\sum_{i=1}^{n} \sum_{j=1}^{n} w_{i j}}\left[\frac{\sum_{i=1}^{n} \sum_{j=1}^{n} w_{i j}\left(X_{i}-\bar{X}\right)\left(X_{j}-\bar{X}\right)}{\sum_{i=1}^{n}\left(X_{i}-\bar{X}\right)^{2}}\right]
$$

It is denoted that $w_{x y}$ is an element of spatial weight matrices. It comprises the information regarding the structure between region $x$ and $y$. $\mathrm{W}_{x y}$ is accorded on dual relationship. Principally, it will equal to 1 if $x$ and $y$ are neighbors and if otherwise, it will be zero. Theory of spatial econometrics explained that the binary weight matrices can be categorized into contiguity-based weight matrices and distance-based weight matrices. In this paper, we use inverse distance-based weight matrices.

\subsubsection{The Moran Scatter Plot}

Spatially lagged values of a variable towards the genuine values of the variable are illustrated by Moran Scatter Plot. It augments Moran's I by dividing the global spatial autocorrelation across locations or regions becoming four quadrants. Quadrant I is high-high $(\mathrm{HH})$ groups (regions with high values of the variable with neighboring regions with high values). Quadrant II is low-high (LH) groups of regions (regions with low values of the variable which surrounded by bordering regions with high values). Meanwhile, low-low (LL) groups of regions are regions with low values of the variable rounded by neighboring regions with low values). Lastly, Quadrant IV is high-low (HL) groups where regions with high values of the variable surrounded by bordering regions with low values). This distribution of Moran's I plot assists to examine both spatial heterogeneity, spatial 
outliers as well. Meanwhile, the parameter for Moran's I are reflected by the slope of the scatter plot.

Given in deviations from the mean, we assume a variable $x$. By applying the row-standardized weights, the total of all the weights $\left(\mathrm{S}_{0}\right)$ will be equal with the total of observations $(p)$. Consequently, the equation for univariate Moran's I extenuates to:

$$
I=\frac{\sum_{i} \sum_{j} w_{i j} x_{i} x_{j}}{\sum_{i} x_{i}^{2}}=\frac{\sum_{i}\left(x_{i} \times \sum_{j} w_{i j} x_{j}\right)}{\sum_{i} x_{i}^{2}}
$$

In addition, another Moran's scatter plot that will be described in this paper is differential Moran's I. This type of Moran is another option to bivariate spatial correlation in one point at time between variable, $t$ with its neighbors in the previous year, $t-1$. The utilization of this differential Moran's $\mathrm{I}$ is organizing the locational fixed effects by distinguishing the variables.

Thus, a differential Moran's I is the slope of a regression from the spatial lag of the difference, which is $\sum_{j} w_{i j}\left(y_{j, t}-y_{j, t-1}\right)$ on the difference $\left(y_{i, t}-y_{i, t-1}\right)$.

\subsubsection{Local Indicators of Spatial Autocorrelation (LISA)}

Anselin et al. (2006) illustrated the significances of spatial clusters or spatial outliers for every region through LIS or Local Moran's Statistics. The most significant regions are the statistically significant spatial clusters, which are often called with hot-spots among the cluster of high-high groups of regions. On the contrary, cold-spots are defined as the most significant regions among the cluster of low-low groups of regions. To simplify, the local Moran's formula for each region $k$ and year $t$ is written as follows:

$$
\begin{aligned}
& I_{k}=\left(\frac{X_{i}-\bar{X}}{m_{0}}\right) \sum_{j=1}^{n} w_{k j}\left(X_{j}-\bar{X}\right) \\
& m_{0}=\sum_{k=1}^{n} \frac{\left(X_{k}-\bar{X}\right)^{2}}{p}
\end{aligned}
$$

Basically, if we calculate LISA for each region on the average, it will be equal to global Moran's I (Anselin 1995, 2007). 


\subsection{Spatial Autoregressive Models}

Spatial dependence among growth processes of sub-national level, in this present paper, district level, may be caused by two types of features. The first feature is correlated with random shocks, symbolized by spatial error models, coming from neighboring regions and another one is correlated with the growth rates of neighboring regions, symbolized by spatial lag models as shown by Fingleton and Lopez-Bazo (2006). Long years before, Anselin (1988) has first introduced two acknowledgable models to recognize spatial dependence. It commonly consists of spatial autoregressive lag model and the spatial autoregressive error model. Spatial autoregressive models broaden the ordinary linear regression through permitting dependent variables in one area to be affected by dependent variables in neighboring areas, covariates from neighboring areas, and errors from neighboring areas. Thus, it comprises of three kind of possible models, which are spatial lags of the dependent variable, spatial lags of independent variables or covariates and lastly spatially autoregressive errors. In this present paper, two models that will be used are spatial autoregressive model with lag of dependent variable model and spatial autoregressive model.

To bring into the growth regression, spatial autoregressive lag model can be introduced as follows:

$$
g y_{i t}=\alpha+\left(e^{\beta T}-1\right) \ln y_{i 0}+\mathbf{X}_{i t}^{\prime} \gamma_{x}+\mathbf{T}_{t}^{\prime} \gamma_{t}+\boldsymbol{\rho} \mathbf{W} g y_{i t}+\eta_{i}+u_{i t}
$$

$\mathbf{W}$ is the spatial weight matrices and $\boldsymbol{\rho} \mathbf{W} g y_{i t}$ is the spatial lag of dependent variable. Apart from that, spatial autocorrelation may happen in the disruption or structure of error term in the estimation. In spatial analysis, it is called as the spatial autoregressive error model (SEM). For more detailed, Anselin (1988) has decomposed sthe structure of the error term into growth regression as follows:

$$
g y_{i t}=\alpha+\left(e^{\beta T}-1\right) \ln y_{i 0}+\mathbf{X}_{i t}^{\prime} \boldsymbol{\gamma}_{\boldsymbol{x}}+\mathbf{T}_{t}^{\prime} \boldsymbol{\gamma}_{\boldsymbol{t}}+\eta_{i}+\left(\mathrm{I}-\zeta \mathbf{W} u_{i t}\right)^{-1} \varepsilon_{i t}
$$

where $u_{i t}=\zeta \mathbf{W} u_{i t}+\varepsilon_{i t}$ is spatial error term. 
Spatial analysis basically is about accounting for spill-over effects. There are two kind of effects that emerge on spatial term. First, direct effect is the effect of a change within the region with neglecting spill-over effects. Second, the indirect effect or spill-over effect that occurs due to region difference, there are different effects that emerged from the influence of its own neighbors.

\subsection{Data}

The regional growth process is approached by Human Development Index (HDI) over time from 2010 to 2018 as the outcome. Starting from 2010, Indonesia revised the methodology of HDI, replacing literacy rate to be expected years of schooling since the literacy rate in Indonesia across districts has obtained the satisfying performance, therefore it was no longer relevant to represent the quality of education. For each dimension, a long and healthy life is reflected by life expectancy, access to knowledge are measured by mean years of schooling and expected years of schooling while for decent living standard, the preceeding proxy used was Gross Domestic Product (GDP) per capita. Since 2010, the indicator for decent living standard on HDI turned into Gross National Product (GNP) per capita. Since GNP is not available for province and district level, it is approached by adjusted per capita consumption expenditure of 92 commodities for both food and non-food expenditures that obtained from National Socio-Economic Survey.

The dataset comprises of 515 districts in Indonesia and all of the data are obtained from BPS-Statistics of Indonesia for 2010-2018 period. The data processing will be conducted by $\mathrm{R}$ for classical convergence analysis, STATA 16 for spatial autoregressive models and Geoda for Global and Local Spatial Autocorrelation.

\section{Results}

\subsection{Human Capital Growth across Districts in Indonesia}

Indonesia consists of hundreds of districts which are separated by islands. Because of its complicated geographic landscape, the equality for all regions is long way to go. As mentioned before, to measure the regional development on 
districts level in Indonesia, the two approaching indicators are considerable to conduct, one of which is Human Development Index. From the latest data of Human Development Index across districts in 2018, it was confirmed that the lowest value of HDI were still contributed by the eastern part of Indonesia (Sulawesi, Maluku, Maluku Utara, NTT, NTB and Papua), typically Papua Islands. Despite of within Papua Islands was still having regions with the high categorized HDI, but it was still dominated by the low and moderate value of HDI (See Figure 1).

Figure 1. Human Development Index across Districts of Indonesia, 2018

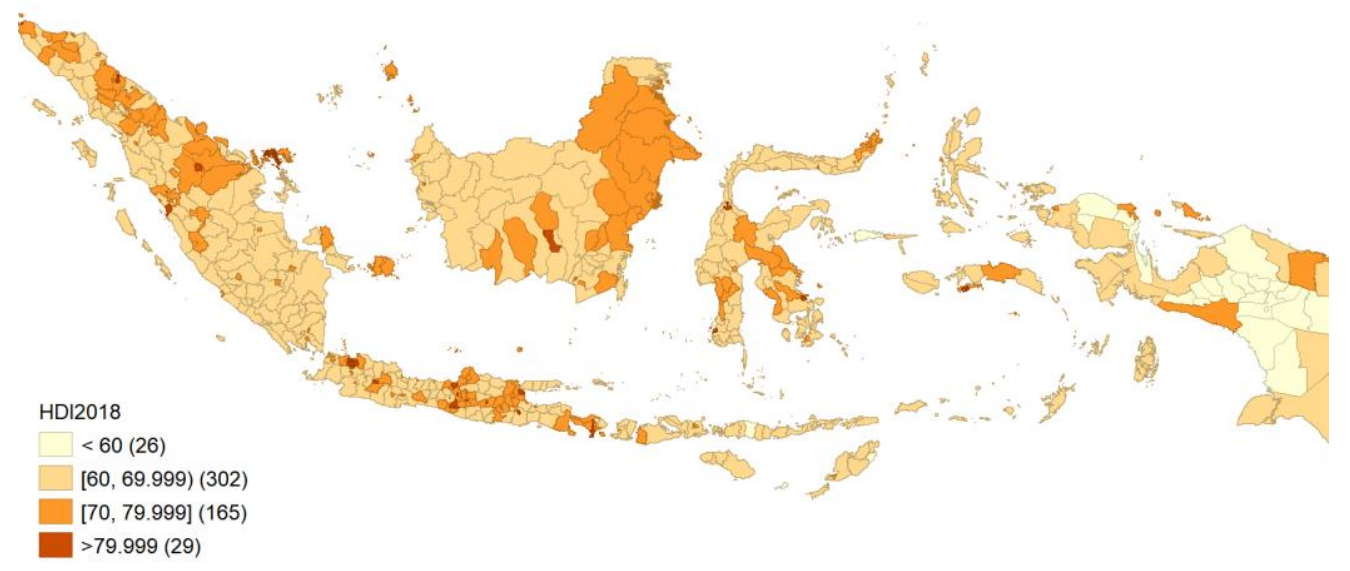

From Figure 1, we can highlight the wide disparity between Papua Island and other islands. It seems inequality of human development still being the major issue even after decentralization period. To draw the more obvious mapping in order to simplify the analysis and policy implementation for government, BPS-Statistics of Indonesia has created categorization and divided all districts into four categories, which are: low, moderate, high and very high with the specification range of HDI as follows ( See Table 1). 
Table 1. Classification of Human Development Index

\begin{tabular}{|c|c|c|}
\hline Groups of HDI & Districts & $\begin{array}{c}\text { HDI } \\
\text { Range }\end{array}$ \\
\hline Very high & $\begin{array}{l}\text { Jakarta (capital city of the country), } \\
\text { Yogyakarta, Sleman, Denpasar, Padang, Banda } \\
\text { Aceh, Salatiga, Kendari }\end{array}$ & $\geq 80$ \\
\hline High & $\begin{array}{l}\text { Medan, Pekanbaru, Dumai, Jambi, Palembang, } \\
\text { Batam, Magelang, Purworejo, Mataram, } \\
\text { Balikpapan, Ternate, Gorontalo, Palopo, } \\
\text { Samarinda, Kota Sorong, Jayapura, Gorontalo }\end{array}$ & $\begin{array}{c}70 \leq \mathrm{HDI} \\
<80\end{array}$ \\
\hline Moderate & $\begin{array}{l}\text { Simelue, Aceh Singkil, Langkat, Kep. } \\
\text { Anambas, Lingga, Mukomuko, Mandailing } \\
\text { Natal, Tapsel, Garut, Cianjur, Tasikmalaya, } \\
\text { Kapuas, Kutai Barat, Bombana, } \\
\text { EnrekangKarangasem, Buleleng, Sumba Barat, } \\
\text { Nabire, Sikka, Barito Selatan, Utara, Ende, } \\
\text { Teluk Bintuni, Manokwari }\end{array}$ & $\begin{array}{c}60 \leq \mathrm{HDI} \\
<70\end{array}$ \\
\hline Low & $\begin{array}{l}\text { Sampang (in East Java provinces, but located } \\
\text { far from capital city of East Java Provinces), } \\
\text { Mentawai, Nias, Timor Tengah Selatan, } \\
\text { Sumba Barat Daya, Rote Nda, Belu, Alor, } \\
\text { Maluku }\end{array}$ & $<60$ \\
\hline
\end{tabular}

Source: Author's calculation using data from BPS-Statistics Indonesia, 2010-2018

Note : Districts that displayed on the table above are only some of the selected districts that represent each category.

Based on the Table 1, the regions of very high HDI represent the characteristics as the capital city of country (Jakarta), center of education (Yogyakarta, Sleman), cultural and tourism resources (Denpasar, Aceh, Padang). Meanwhile, the regions of high HDI are generally capital cities of provinces or close to the capital cities of provinces (Medan, Pekanbaru, Dumai, etc). For moderate, the regions are not too close with economic hubs, but still reachable to 
the capital cities of provinces. Lastly, the low HDI group are usually in quite or very far distance from center of government and economic hubs, or geographically located in separated or remoted islands (Mentawai, Nias, Rote Nda, Sampang).

Moving to the average growth rate, during last decade, Indonesia has shown better performance on human capital growth for all aspects, with the highest growth rate of HDI emerges from eastern part of Indonesia, the groups in which the inequality gap are wide and development level is still falling behind. However, during 2010-2018 period, even they have indicated better improvement to catch up, unfortunately the lowest values of HDI are still contributed from these groups.

Figure 2. Human Development Index Growth Rate across Districts in Indonesia, 2010-2018

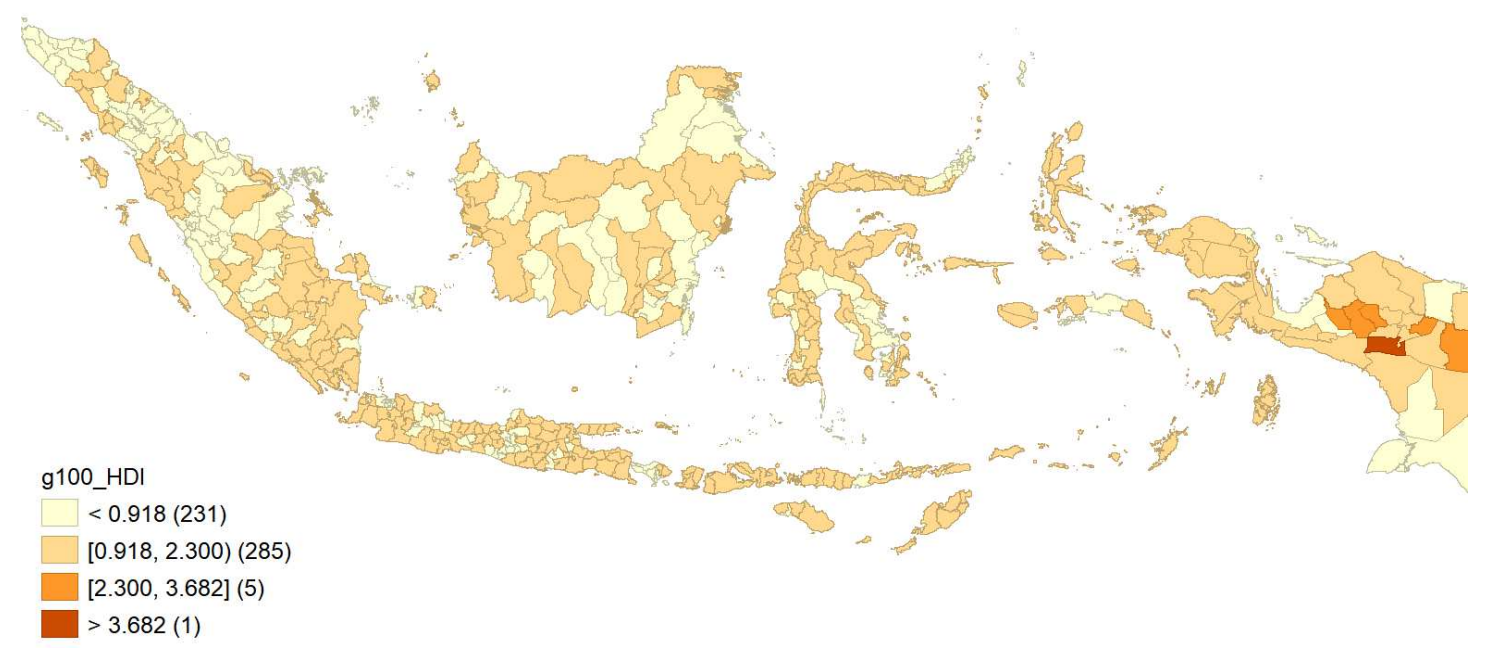

Through Figure 2 as the stylized facts, we can observe that the highest growth rate of HDI during 2010-2018 came from the eastern part of Indonesia. We may argue with aligned theory of neoclassical growth model suggesting that in a point of time, the poor economies ( in this case poor human development) will grow faster than the rich development) since the capital growth rate tends to be proportionally inverted to the beginning level of output per region. Thus, due to these reasons, there is coming a force to motivate convergence process in level of human development growth. It is confirmed by Indonesia's districts case that proved the highest growth rate eventually comes from the less developed 
economies (human capital) meaning that very low initial level of output region can catch-up their falling behind status.

\subsection{Classical Convergence}

Some studies have proved that convergence may occur in sub-national level because of the spill-over effect is greater. In Indonesia, human development also grow faster in the less developed districts rather than the more developed or advantageous districts. Through Table 2, we can confirm that convergence exists for the growth process in human development across districts. It is reflected by the significance of $\beta$ - convergence (the sign is negative) for Human Development Index and all its determinants or indicators. The speed of convergence for HDI is 2.6 percent with the half-life of 26.35 years. It means that Indonesia may need around 26 years for the less developed districts (commonly eastern parts and border districts) to close the 50 percent of gap from more developed districts. In addition, for its determinants, among four variables, it seems that education access, which are expected years of schooling and mean years of schooling are the main triggers in the growth process to HDI convergence.

Table 2. Beta Convergence of Human Development Index and Its Determinants, 2010-2018

\begin{tabular}{llllllc}
\hline \multicolumn{1}{c}{ Variable } & $\begin{array}{c}\beta- \\
\text { convergence }\end{array}$ & t-statistic & $\begin{array}{c}p- \\
\text { value }\end{array}$ & $\begin{array}{c}\text { Speed of } \\
\text { Convergence }\end{array}$ & $\begin{array}{c}\text { Half- } \\
\text { Life }\end{array}$ & $\begin{array}{c}\text { R- } \\
\text { square }\end{array}$ \\
\hline $\begin{array}{l}\text { Human } \\
\begin{array}{l}\text { Development } \\
\text { Index }\end{array}\end{array}$ & -0.19 & -41 & $0.000^{*}$ & 0.026 & 26.35 & 0.77 \\
\hline Life Expectancy & -0.109 & -11 & $0.000^{*}$ & 0.014 & 48.13 & 0.2 \\
\hline $\begin{array}{l}\text { Mean Years of } \\
\text { Schooling }\end{array}$ & -0.239 & -35 & $0.000^{*}$ & 0.034 & 20.26 & 0.71 \\
\hline $\begin{array}{l}\text { Expected Years } \\
\text { of Schooling }\end{array}$ & -0.311 & -36 & $0.000^{*}$ & 0.047 & 14.883 & 0.72 \\
\hline $\begin{array}{l}\text { Gross National } \\
\text { per Capita }\end{array}$ & -0.077 & -9.8 & $0.000^{*}$ & 0.01 & 69.28 & 0.16 \\
\hline
\end{tabular}

Source: Author's calculation using data from BPS-Statistics Indonesia, 2010-2018 Note: * indicates significant at $1 \%, 5 \%$ and $10 \%$ level

From the the theory on literature review, we have known that significance of beta convergence is not adequate to confirm the existence of sigma convergence. However, from Table 3 below, we can observe that sigma 
convergence also occurs on the growth process of HDI in Indonesia. It not only exists for Human Development Index, but also for its determinants at all level of significance, except Gross National per Capita ( $p$-value is not significant at $1 \%, 5 \%$ and $10 \%$ level).

Table 3. Sigma Convergence of Human Development Index and Its Determinants, 2010-2018

\begin{tabular}{cccccc}
\hline Variables & $\begin{array}{c}\text { Human } \\
\text { Development } \\
\text { Index }\end{array}$ & $\begin{array}{c}\text { Life } \\
\text { Expectancy }\end{array}$ & $\begin{array}{c}\text { Mean Years } \\
\text { of Schooling }\end{array}$ & $\begin{array}{c}\text { Expected } \\
\text { Years of } \\
\text { Schooling }\end{array}$ & $\begin{array}{c}\text { Gross } \\
\text { National } \\
\text { per } \\
\text { Capita }\end{array}$ \\
\hline $\begin{array}{c}\text { Dispersion } \\
\text { in 2010 }\end{array}$ & 0.13 & 0.057 & 0.32 & 0.18 & 0.28 \\
\hline $\begin{array}{c}\text { Dispersion } \\
\text { in 2018 }\end{array}$ & 0.1 & 0.052 & 0.25 & 0.13 & 0.26 \\
\hline $\begin{array}{c}\text { Dispersion } \\
\text { ratio }\end{array}$ & 1.22 & 1.09 & 1.29 & 1.4 & 1.06 \\
\hline F-statistic & 1.5 & 1.2 & 1.7 & 2 & 1.1 \\
\hline$p$-value & $0.000^{*}$ & 0.050 & $0.000^{*}$ & $0.000^{*}$ & 0.160 \\
\hline
\end{tabular}

Source: Author's calculation using data from BPS-Statistics Indonesia, 2010-2018

Note: * indicates significant at $1 \%, 5 \%$ and $10 \%$ level

\subsection{Spatial Autocorrelation and Spatial Autoregressive Models}

\subsubsection{Moran's I and Moran's I Scatter Plot}

Refers to one of the research questions above, this paper aims to examine the existence of spatial dependence for the outcome, i.e. Human Development Index. To start with, we check the existence of spatial dependence through global spatial autocorrelation and local spatial autocorrelation. Global spatial autocorrelation is measured by Moran's I value and Moran's I scatter plot. However, in this paper, two types of Moran's I are conducted, univariate Moran's I and differential Moran's I. The purpose are to control the locational fixed effect and test the robustness of temporary correlation that may be appeared as the consequences of fixed effect, i.e. a set of variables that confirm the value of its own which does not change over time. Table 4 declares the positive spatial dependence for Human Development Index and its determinants. It can be seen from Table 4 showing the positive value of Moran's I of HDI and its indicators. It means that the growth process of regional human development is dependent, not random. Therefore, any kind of 
strives in a region or district can not be separated from the development and growth from its neighbors.

Table 4. Moran's I Values of HDI and Its Indicator 2010-2018

\begin{tabular}{|c|c|c|c|c|c|c|c|c|c|c|}
\hline \multirow[t]{2}{*}{ Year } & \multicolumn{2}{|c|}{ HDI } & \multicolumn{2}{|c|}{ Life Expectancy } & \multicolumn{2}{|c|}{$\begin{array}{l}\text { Mean Years of } \\
\text { School }\end{array}$} & \multicolumn{2}{|c|}{$\begin{array}{c}\text { Expected Years } \\
\text { of School }\end{array}$} & \multicolumn{2}{|c|}{$\begin{array}{l}\text { Gross National } \\
\text { Product per } \\
\text { Capita }\end{array}$} \\
\hline & Uni & Diff & Uni & Diff & Uni & Diff & Uni & Diff & Uni & Diff \\
\hline 2010 & 0.445 & - & 0.589 & - & 0.353 & - & 0.397 & - & 0.422 & - \\
\hline 2011 & 0.444 & 0.145 & 0.589 & 0.139 & 0.347 & 0.033 & 0.395 & 0.044 & 0.433 & 0.373 \\
\hline 2012 & 0.446 & 0.115 & 0.594 & 0.298 & 0.343 & 0.025 & 0.398 & 0.028 & 0.443 & 0.439 \\
\hline 2013 & 0.446 & 0.164 & 0.597 & 0.344 & 0.33 & 0.018 & 0.404 & 0.075 & 0.44 & 0.303 \\
\hline 2014 & 0.445 & 0.089 & 0.596 & -0.121 & 0.327 & 0.058 & 0.407 & 0.119 & 0.441 & 0.144 \\
\hline 2015 & 0.452 & 0.026 & 0.603 & 0.026 & 0.328 & -0.037 & 0.417 & 0.035 & 0.443 & 0.236 \\
\hline 2016 & 0.456 & 0.01 & 0.606 & 0.01 & 0.332 & 0.002 & 0.433 & -0.002 & 0.447 & 0.254 \\
\hline 2017 & 0.455 & 0.147 & 0.609 & 0.147 & 0.339 & 0.045 & 0.433 & 0.007 & 0.447 & 0.11 \\
\hline 2018 & 0.456 & 0.139 & 0.607 & 0.541 & 0.344 & 0.065 & 0.418 & 0.089 & 0.458 & 0.547 \\
\hline
\end{tabular}

In addition, if we have a look from differential Moran's I value, we can see obviously the correlation over time and the changing pattern as well. Moreover, since differential Moran's I value measure the value difference between one variable at one point of time and the previous year, it is obtained negative spatial dependence for some indicators, like life expectancy, mean years of schooling and expected years of schooling ( See Table 4). However, observing from univariate Moran's value, the correlation does not change much over time. Due to that reason, to check the robustness and control the locational fixed effects, the differential Moran's I is also conducted as illustrated by Figure 3 below. 
Figure 3. Moran Scatter Plot 2010-2018 of Human Development Index and Its Determinants

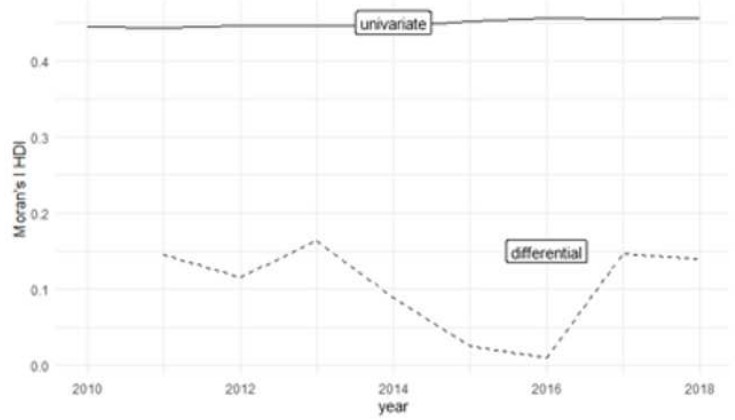

(a) Moran's I Statistics for HDI

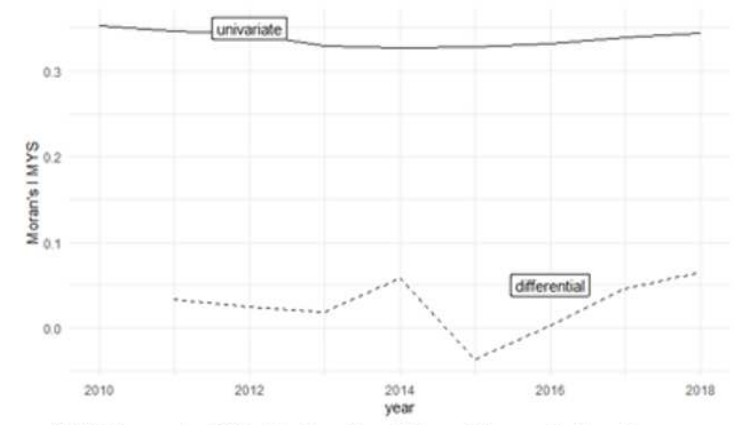

(c) Moran's I Statistics for Mean Years School

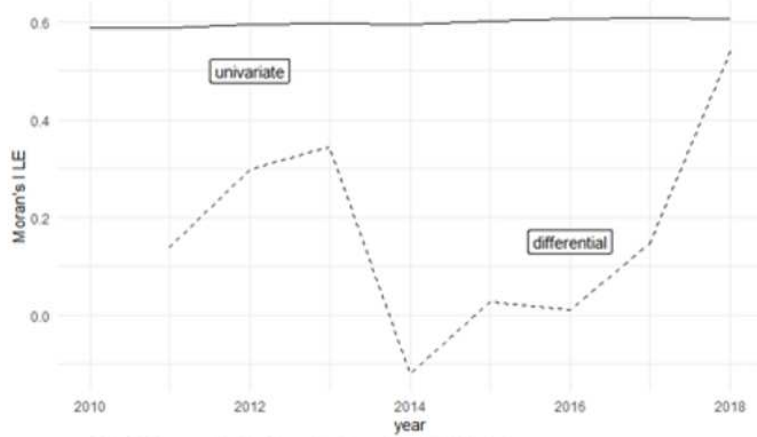

(b) Moran's I Statistics for Life Expectancy

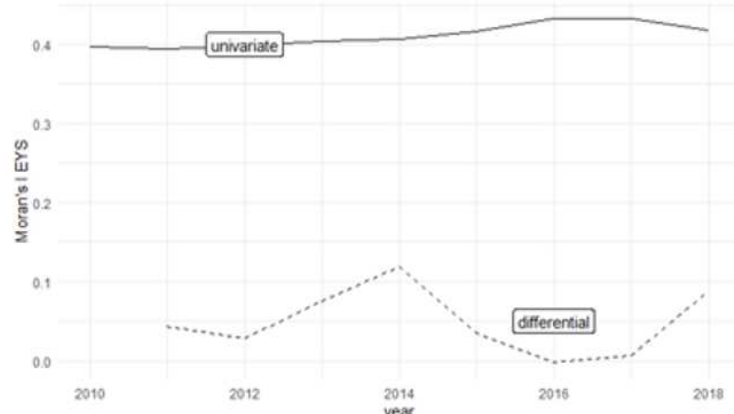

(d) Moran's I Statistics for Expected Years School

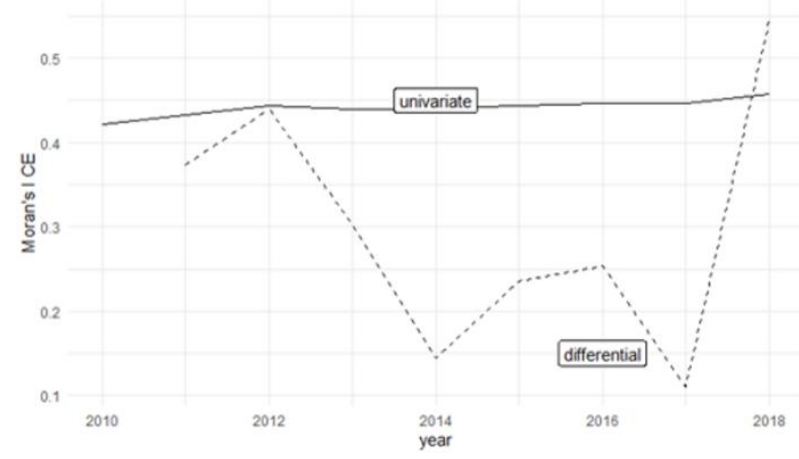

(e) Moran's I Statistics for Gross National Product per Capita

\subsubsection{Local Indicators of Spatial Autocorrelation}

In this paper, LISA cluster maps the outcome into the growth rate of HDI during 2010-2018 period. The aim is to check the existence of spatial clusters which are the cold-spots and hot-spots and spatial outliers as well. From LISA, we can investigate preliminary analysis for how the neighboring regions associated for the growth process on the convergence of human development across districts. From Figure 4, we can see the grey regions are the insignificant regions for local spatial autocorrelation. Even if the Moran's I 
values indicate the spatial dependence between regions, nevertheless it is less affected each other. Nevertheless, the colored out of grey regions are those which indicated the existence of spatial clusters and spatial outliers. Specifically in Papua Islands, many of the districts that strive to go through the catch-up process. It is seen from the highest achievement of HDI growth rate (Raja Ampat, Asmat districts) within 8 years (the red color regions, called $\mathrm{HH}-$ spots or hot-spots). However, this condition seems not greatly affecting the speed of convergence to other neighboring districts, since there are still found low growth rate of HDI regions (Bombana, Nabire and other violet color regions) that surrounded by the high growth of HDI. We can argue that spatial effect is there, but the influence is not that much. The outlier outcomes still occur on the eastern part of Indonesia.

Figure 4. LISA of Human Development Index Growth Rate, 2010-2018

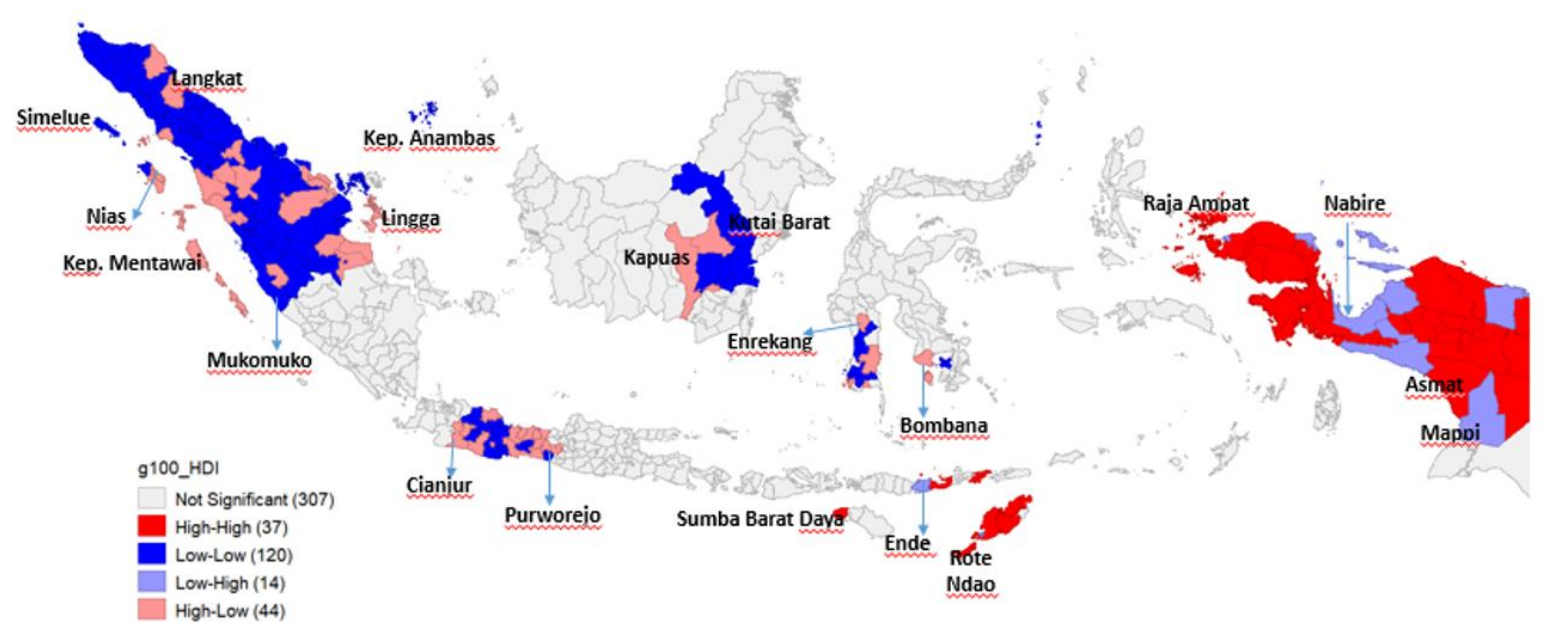

Another example from the contrary side, western part of Indonesia (consists of Sumatra, Java, Kalimantan), we also still find the spatial outliers most in Sumatra, and least in Java and Kalimantan. Since Java and Sumatra are the most developed islands of others, they are dominated by low-low group districts (blue color or cold-spots) which indicate they achieved low growth rate of HDI during 2010-2018. It does not mean that they are underdeveloped, yet it reflects that they have obtained the diminishing return of capital since the level of capital per labor has already been relatively high in these regions, following Solow growth model. This condition leads in turn to catch up 
convergence in poorer regions. However, there are still found the districts among them that still struggle for catching up such as Mukomuko, Kep. Mentawai, Lingga, Nias and Kapuas.

\subsubsection{Spatial Autoregressive Models}

To test whether the spatial spill-over effects affect the human development index on the process of convergence, we consider the inclusion of spatial lag and spatial error model into the human capital growth regression. In this case, the spatial autoregressive lag that used is the lag of dependent variable. Table 5 below compares the parameter estimation, both $\beta$ convergence and speed of the convergence. As we can see that the inclusion of those lag and error models make the convergence process remains significant across districts. However, surprisingly, the speed of convergence experiences much declining.

Table 5. Results of Parameter Estimation from Non-Spatial and With Spatial effects (Spatial Lag/SAL and Spatial Error Model/SEM)

\begin{tabular}{|c|c|c|c|c|c|c|}
\hline \multirow[b]{2}{*}{ Variable } & \multicolumn{2}{|c|}{$\begin{array}{c}\text { Pooled OLS } \\
\text { (Without Spatial Effect) }\end{array}$} & \multicolumn{2}{|c|}{ SAL } & \multicolumn{2}{|r|}{ SEM } \\
\hline & $\beta$ - conv & Speed of conv & $\beta-\operatorname{conv}$ & Speed of conv & $\beta-\mathrm{conv}$ & $\begin{array}{l}\text { Speed of } \\
\text { conv }\end{array}$ \\
\hline $\begin{array}{l}\text { Human } \\
\text { Development } \\
\text { Index }\end{array}$ & $-0.19 *$ & 0.026 & $-0.0248 *$ & 0.0031 & $-0.0248 *$ & 0.0031 \\
\hline Life Expectancy & $-0.109 *$ & 0.014 & $-0.0172 *$ & 0.0022 & $-0.0171 *$ & 0.0022 \\
\hline $\begin{array}{l}\text { Mean Years of } \\
\text { Schooling }\end{array}$ & $-0.239 *$ & 0.034 & $-0.0297 *$ & 0.0038 & $-0.0299 *$ & 0.0038 \\
\hline $\begin{array}{l}\text { Expected Years of } \\
\text { Schooling }\end{array}$ & $-0.311 *$ & 0.047 & $-0.0391 *$ & 0.005 & $-0.0401 *$ & 0.0051 \\
\hline $\begin{array}{l}\text { Gross National } \\
\text { per Capita }\end{array}$ & $-0.077 *$ & 0.01 & $-0.0129 *$ & 0.0016 & $-0.0108 *$ & 0.0014 \\
\hline
\end{tabular}

Note: STATA is used to estimate the parameter. * indicates the parameters are significant at $1 \%, 5 \%$ and $10 \%$ level of significance

Interestingly, we can investigate how far spatial spill-over effects go through the separation of the effects. In spatial analysis, it is well-known that the effects that emerge to influence the outcome do not only come from the factors or explanatory variables within a region, yet we also should take into consideration the neighborhood effect that come from out of the region, i.e. its 
own neighboring areas. The effect that comes within the region is called direct effect, meanwhile the spatial spill-over effect is called with indirect effect. Based on Table 6, we can find that for Indonesia district case, the effect on outcome is dominated by the direct effect meaning that the factors within region influences greater than the effect coming from its neighbors. It is confirmed by finding of Vidyattama (2013) for 1998-2008 declared that neighborhood effect on human development convergence was significantly exist, however the speed was declining. It is reasonable since decentralization has been implemented for more than a decade and each district or region is accountable for their own regional development. Apart from that, each local government was fully given authority for the policy making.

Table 6. Direct and Indirect Effects of Two Spatial Autoregressive Models

\begin{tabular}{lcccc}
\hline \multirow{1}{*}{ Variable } & \multicolumn{2}{c}{ Spatial Lag Model } & \multicolumn{2}{c}{ Spatial Error Model } \\
\cline { 2 - 5 } & $\begin{array}{c}\text { Direct } \\
\text { effect }\end{array}$ & $\begin{array}{c}\text { Indirect } \\
\text { effect }\end{array}$ & $\begin{array}{c}\text { Direct } \\
\text { effect }\end{array}$ & $\begin{array}{c}\text { Indirect } \\
\text { effect }\end{array}$ \\
\hline $\begin{array}{l}\text { Human Development } \\
\text { Index }\end{array}$ & -0.0249 & -0.0035 & -0.0252 & - \\
\hline Life Expectancy & -0.0171 & 0.0826 & -0.0171 & - \\
\hline $\begin{array}{l}\text { Mean Years of } \\
\text { Schooling }\end{array}$ & -0.0298 & 0.0033 & -0.0299 & - \\
\hline $\begin{array}{l}\text { Expected Years of } \\
\text { Schooling }\end{array}$ & -0.0391 & -0.0016 & -0.0401 & - \\
\hline $\begin{array}{l}\text { Gross National per } \\
\text { Capita }\end{array}$ & -0.013 & -0.0052 & -0.0108 & - \\
\hline Note: STATA 16 is conducted for estimating the parameters ( direct and indirect effects) &
\end{tabular}

From Table 6 above, we can observe that the own-region effect is much affecting than that of indirect as much 0.0249 percentage point for Human Development Index. It means that 1 percentage point increases on the initial output level of HDI in a region is to reduce 0.0249 percentage points the growth rate of HDI in that region. On the contrary, the indirect or spill-over effect reduce the annual growth rate of HDI as much 0.0035 percentage points using spatial lag model. It also occurs for other determinants showing the inclusion of spatial lag and error will slow the speed of convergence. However, when we apply spatial error model, the indirect effect will be not present because the lagged variable for dependent or covariate is not utilized in this 
case. Thus, there will be no spill-over effects. In addition, spatial error also will not generate neighborhood effect for the covariate.

\section{Concluding Remarks}

As we have addressed the purposes of this study, there are fourfold aims that has been analyzed. Regarding the human capital growth and its determinant, it is sufficient to reveal that beta convergence significantly exists on the growth process of human development and its indicators, so do with the sigma convergence even though gross national product per capita is not significant. The speed of convergence among the determinants that assumed boosting the process of convergence are expected years of schooling and mean years of schooling variable, in this case, education aspect.

For the spatial dependence examination, we also have tested through global and local spatial autocorrelation that the presence of spatial autocorrelation across districts in Indonesia does significantly exists. It is confirmed through Moran's I scatter plot for both univariate and differential to ensure the robustness and control the locational fixed effects that might occur. Through LISA, we also can classify some hot-spots and cold-spots regions in term of growth rate of HDI and the spatial outliers as well, indicating the spatial heterogeneity where low growth regions are surrounded by high growth rate regions, vice versa.

Related to the role of spatial spill-over effects and to analyze how far it plays its function, Spatial Lag Model and Spatial Error Model are conducted. The finding is the convergence is still significant for human development and its determinants, however with 2010-2018 data the speed of convergence is much declining compared to the exclusion of lag and error term. It is in line with the study of regional convergence in another country, Niebuhr (2001) and Kosfeld et.al. (2002) stated that spill-over effect influenced the growth process, yet it lowered the speed significantly.

The results of this paper will bring into some policy implications that the local government play the greatest role for achieving the rapid growth of HDI, especially in the eastern part of Indonesia ( Papua, etc), let alone the decentralization era has forced policy maker at sub-national level to develop 
their region actively. In addition, even though spill-over effect from neighboring regions is only a little and tends to slow the convergence speed, it can be possible for a call on active regional policy by involving higher levels of investment on human capital aspects especially for education aspects in remote and outer island districts to assist them accelerating the catching-up process. Better combination with infrastructure access is needed especially in eastern regions that enable to strengthen the linkage between the developed and developing regions with more dynamic markets in Indonesia.

Lastly, for the upcoming research, the results of this paper will deliver some milestones. In term of methodology, it might better to apply the panel data spatial autoregressive model with inclusion of random effects and include policy variables such as government expenditures or regional budgets, institutional determinants such as red tape and corruptions. 


\section{References}

Abreu, M., H. L. F. de Groot, and R. J. G. M. Florax. (2004). "Space and Growth: A Survey of Empirical Evidence and Methods." Tinbergen Institute Working Paper No. TI 04-129/3. http://ssrn.com/abstract_631007

Anand, S. and Sen, A. (2000) 'The income component of the Human Development Index', Journal of Human Development 1 (1): 83-106

Anselin, L. (1988) Spatial Econometrics: Methods and Models, Kluwer Academic Publishers, Dordrecht, Netherlands.

Anselin L (1995) Local indicator of spatial association-LISA. Geogr Anal 27(2):93-115

Anselin, L., Syabri, I., and Kho, Y. (2006). Geoda: an introduction to spatial data analysis.

Geographical analysis, 38(1):5-22

Anwar, A. (2018). Empirical Analysis of Human Capital Convergence in Indonesia. JEJAK: Jurnal Ekonomi dan Kebijakan, 11(2),306-322

Barro, R.J. (1991). Economic Growth in a Cross Section of Countries. The Quarterly Journal of Economics, 1062, pp. 407-443.

Barro, R.J. (1996). Democracy and Growth. Journal of Economic Growth, 1(1), pp.1-27. Barro, R.J. and Lee, J.W. (1994). Sources of Economic Growth (with comments from Nancy Stokey). Carnegie-Rochester Conference Series on Public Policy, 40, pp.1-57.

Barro, R.J. and Sala-I-Martin, X. (1991). Convergence across States and Regions. Brookings Papers on Economic Activity, 1, pp. 107-182.

Cravo, A. C., B. Becker, and A. Gourlay. 2015. "Regional Growth and SMEs in Brazil: A Spatial Panel Approach.” Regional Studies 49 (12): 1995-2016.

Cuaresma, J. Crespo, G. Doppelhofer, and M. Feldkircher. 2014. "The Determinants of Economic Growth in European Regions.” Regional Studies 48 (1): 44-67

Esiyok, Bulent and Ugur, Mehmet. (2017). Spatial Dependence in the Growth Process and Implications for Convergence Rate: Evidence on Vietnamese Provinces. Journal of The Asia Pacific Economy, 2017 https://doi.org/10.1080/13547860.2017.1351764 
Garcia-Garcia, J. and Soelistianingsih, L. (1998). Why Do Differences in Provincial Incomes Persist in Indonesia? Bulletin of Indonesia Economic Studies, 34(1), pp. 95-120.

Kharisma, Bayu and Saleh, Samsubar. (2013). Converge of Income among Provinces in Indonesia 1984-2008: A Panel Data Approach. Journal of Indonesian Economy and Business Volume 28, Number 2, 2013, 167 - 187

Kosfeld, R., Eckey, H.F. and Dreger, C. (2002) 'Regional convergence in unifed Germany:

A spatial econometric perspective', Economic Discussion Paper No. 39/02, University

of Kassel, Germany.

Le Sage, J. P., and M.F. Fischer. 2008. "Spatial Growth Regressions: Model Specification, Estimation and Interpretation.” Spatial Economic Analysis 3 (3): 275-304.

Lima, R .C . A., and R .M . S.N eto. 2016. "Physical and Human Capital and Brazilian Regional Growth: A Spatial Econometric Approach for the Period1970-2010." RegionalStudies50 (10): 1688-1701.

Mohl, P., and T. Hagen. 2010. "Do EU Structural Funds Promote Regional Growth? New Evidence from Various Panel Data Approaches." Regional Science and Urban Economics 40 (5): 353-365.

Mendez, C. (2018). On the Distribution Dynamics of Human Development: Evidence from the Metropolitan Regions of Bolivia. Economics Bulletin, 38(4):2467-2475.

Mohanty, Biswajit and Bhanumurthy, N.R.(2018). Regional Growth Policy Experience in India : The Spatial Dimension. Journal of The Asia Pacific Economy, 2017. https://doi.org/10.1080/13547860.2017.1351764

Niebuhr, A., (2001) 'Convergence and the effects of spatial interaction', Jahrbuch für Region-alwissenschaft 21: 113-33.

Ramos,Raul, et.al.(2009). Human Capital Spillovers and Regional Economic Growth in Spain. https://www.researchgate.net/publication/254412286 
Resende, G. M., A. X. Y. de Carvalho, P.A.M. Sakowski, and T. A. Cravo. 2016. "Evaluating Multiple Spatial Dimensions of Economic Growth in Brazil Using Spatial Panel Data Models.” The Annals of Regional Science 56 (1): 1-31.

Resosudarmo, B. and Vidyattama, Y. (2006). Regional Income Disparity in Indonesia: A Panel Data Analysis. ASEAN Economic Bulletin, 23(1), pp. 3144.

Sala-I-Martin, X. (1996) 'Regional cohesion: evidence and theories of regional growth and convergence', European Economic Review 40: 1325-52.

Vidyattama, Yogi.(2013). Regional Convergence and The Role of The Neighbourhood Effect in Decentralised Indonesia. Bulletin of Indonesian Economic Studies, Vol. 49, No. 2, 2013: 193-211. http://dx.doi.org/10.1080/00074918.2013.80984 